\title{
PELAPORAN KERUGIAN PENURUNAN NILAI GOODWILL SERTA DAMPAKNYA TERHADAP NILAI PERUSAHAAN
}

\author{
Nunung Nuryani \\ Ilham Samsudiono \\ Kwik Kian Gie School of Business
}

\begin{abstract}
This study objective is to examine the determinants of the firm's tendency to report goodwill impairment losses and it's impact on the value of the firms. The agency theory states that managers may take some advantages of information asymmetry and utilize the accounting methods choice for private motives. Consistent with the theory, the new accounting standard for goodwill has given some flexibilities to managers to act opportunistic. On the other hand, the signaling theory explains that goodwill impairment losses is considered as bad news by investors because it relates to the decrease of the firm's ability to generate cash inflow in the future, that will ultimately affect the value of the firm.

We find that the reporting incentive (income smoothing), firm performance, 'and auditor quality affects the firm's tendency to report goodwill impairment loss, while the debt covenant does not affect the firm's tendency to report goodwill impairment loss. We also find that reported goodwill impairment loss affects the firm's value.
\end{abstract}

Keywords: Reporting incentives, firm performance, audit quality, goodwill impairment losses and firm value.

\section{PENDAHULUAN}

Salah satu isu penting yang terkait kualitas informasi dalam laporan keuangan adalah keandalan informasi atas pelaporan aset tak berwujud, yang bila dibandingkan dengan total aset perusahaan dalam laporan keuangan saat ini menunjukkan persentase yang cukup tinggi. Salah satu aset tak berwujud perusahaan yang terus mengalami peningkatan dalam pelaporannya adalah goodwill (Kieso, et al., 2011). Berdasarkan salah satu hasil penelitian yang dilakukan oleh KPMG pada tahun 2008, nilai goodwill per total aset rata-rata dapat mencapai 10 persen pada perusahaan go public di Amerika Serikat (Maria E.Orlante,2011). Peningkatan nilai goodwill yang dilaporkan perusahaan tersebut menunjukkan bahwa keberadaan goodwill menjadi sangat penting sehingga dibutuhkan pemahaman mengenai keandalan nilai goodwill yang dilaporkan serta perlunya standar akuntansi untuk goodwill yang memadai, sehingga informasi goodwill dapat bermanfaat dalam pengambilan keputusan ekonomik.

Agar informasi tentang goodwill dapat lebih bermanfaat, para penyusun standar nasional maupun internasional telah sepakat untuk menetapkan bahwa goodwill tidak lagi diamortisasi selama masa manfaatnya, namun perusahaan diwajibkan untuk melakukan tes penurunan nilai (impairment test) goodwill minimal sekali dalam setahun atau pada saat adanya kemungkinan terjadinya penurunan nilai goodwill. Standar akuntansi goodwill yang berlaku saat ini, baik International Financial Reporting Standards (IFRS 3, IAS 36, dan IAS 38), US GAAP (Standar Akuntansi Keuangan di Amerika Serikat, yaitu SFAS 141 dan 
SFAS142), dan Pernyataan Standar Akuntansi Keuangan di Indonesia (PSAK 2012: No. 19, 22 dan 48 ) telah konvergen. Tujuan dari penetapan standar akuntansi untuk goodwill tersebut adalah untuk meningkatkan kualitas pelaporan goodwill dan aset tak berwujud lainnya karena dapat merefleksikan kondisi ekonomi yang sebenarnya atas aset tak berwujud tersebut. Namun, berbagai penelitian yang dilakukan beberapa tahun terakhir menunjukkan bahwa standar akuntansi goodwill memberikan sejumlah fleksibilitas kepada manajer untuk melakukan tindakan oportunistik. Tindakan oportunistik ini dapat dilakukan dalam menetapkan nilai pasar goodwill ketika menguji penurunan nilainya. Hal tersebut didukung oleh hasil penelitian terdahulu yang membuktikan bahwa standar akuntansi yang menghapus amortisasi goodwill tersebut justru menurunkan kualitas laporan keuangan (Ramanna, 2011).

Fokus utama berbagai penelitian terdahulu berkaitan dengan goodwill adalah pengujian faktor-faktor yang mempengaruhi keputusan perusahaan dalam melaporkan kerugian penurunan nilai goodwill. Faktor-faktor yang mempengaruhi kerugian penurunan nilai goodwill yang telah diteliti yaitu antara lain: faktor insentif pelaporan (Amel Zadeh, 2013; Karin Feist, 2013; Jamilla Lemans, 2012; Zining Li, 2010; Van De Poel, 2008; Beaty dan Weber, 2006), kinerja keuangan perusahaan (Abdul Majid,2013; Milena,2012; Jane dan Kati,2012; Maria E.Orlante, 2011; Kevin K. Li, 2009; henry Jarva, 2009), dan kualitas auditor (Jamilla Lemans, 2012; Van de Poel, 2008). Hasil penelitian yang telah dilakukan oleh para peneliti terdahulu memberikan hasil yang beragam. Milena (2011) dan Van de Poel (2008) meneliti pengaruh faktor insentif pelaporan keuangan dan faktor kinerja keuangan perusahaan terhadap keputusan pelaporan kerugian penurunan nilai goodwill. Hasil penelitian keduanya menunjukkan bahwa insentif pelaporan lebih cenderung mempengaruhi keputusan pelaporan kerugian penurunan nilai goodwill dibandingkan dengan faktor kinerja keuangan. Namun penelitian terbaru yang dilakukan oleh Lemans (2012) memberikan hasil yang berbeda dengan penelitian Milena (2011) dan Van de Poel (2008). Lemans (2012) menemukan bahwa pelaporan kerugian penurunan nilai goodwill justru tidak dipengaruhi oleh insentif pelaporan namun lebih dipengaruhi oleh kinerja keuangan perusahaan. Selain itu, Lemans juga tidak menemukan cukup bukti bahwa kualitas auditor (Big4 dan Non Big4) turut mempengaruhi keputusan pelaporan kerugian penurunan nilai goodwill.

Selain pengujian faktor-faktor yang mempengaruhi pelaporan kerugian penurunan nilai goodwill, beberapa peneliti menguji dampak yang ditimbulkan ketika perusahaan melaporkan adanya kerugian penurunan nilai goodwill, diantaranya mengenai: reaksi pemegang saham dan kreditur terhadap kerugian penurunan nilai goodwill (Zadeh, 2013; Milena, 2012; Paul dan Laura, 2011; Kevin dan Amir, 2010; Zining Li, 2010; Daniel D.Chambers, 2007), serta menguji apakah pelaporan kerugian penurunan nilai goodwill memiliki relevansi nilai (Knauer, 2012; Changling Chen, 2004; Kevin Li, 2013; Paul Van Huzen,2011; Geoff Mecks,2010). Penelitian Zadeh (2013), Kevin Li (2010), dan Abughazaleh et. al (2012) yang menemukan bahwa pelaporan kerugian penurunan nilai goodwill memiliki relevansi nilai. Hasil penelitian tersebut berbeda dengan hasil penelitian Laura (2011) yang menyatakan bahwa pelaporan amortisasi goodwill lebih memiliki relevansi nilai dibandingkan dengan pelaporan kerugian penurunan nilai goodwill. Namun Milena (2011) menemukan bukti bahwa pelaporan 
kerugian penurunan nilai goodwill mempengaruhi credit rating perusahaan (Milena,2011).

Isu-isu goodwill sangat menarik untuk diteliti karena sangat relevan dengan regulasi yang berkaitan dengan standar akuntansi goodwill yang baru berlaku efektif di Indonesia sejak Januari 2011. Mengacu pada penelitianpenelitian terdahulu sebagaimana diuraikan di atas, penelitian ini bertujuan untuk memberikan tambahan bukti empiris tentang pengaruh faktor insentif pelaporan, kinerja keuangan perusahaan dan kualitas audit terhadap keputusan perusahaan dalam melaporkan kerugian penurunan nilai goodwill. Selain itu, penelitian ini juga bertujuan untuk menguji dampak pelaporan kerugian penurunan nilai goodwill terhadap nilai saham perusahaan. Hasil penelitian diharapkan dapat memberikan kontribusi untuk mendukung hasil penelitian terdahulu dan teoriteori akuntansi positif, serta kontroversi tentang penerapan standar akuntansi goodwill.

\section{KAJIAN PUSTAKA}

Goodwill adalah suatu aset yang mencerminkan manfaat ekonomi masa depan yang timbul dari aset lainnya yang diperoleh dalam kombinasi bisnis yang tidak dapat diidentifikasi secara individual dan diakui secara terpisah. (IAS 36, 2012). Goodwill adalah aset tak berwujud yang paling unik karena tidak seperti aset tak berwujud yang lainnya, goodwill tidak dapat dipisahkan dari keseluruhan unit bisnis dan juga tidak dapat diperjualbelikan secara terpisah (Arnold J. Pahler, 2000). Standar akuntansi yang berlaku secara internasional berkaitan dengan goodwill, yaitu IFRS 3, IAS 36, dan IAS 38 telah diadopsi dalam Pernyataan Standar Akuntansi Keuangan di Indonesia (PSAK 19, PSAK 22, dan PSAK 48) berlaku sejak 1 Januari 2011, menyatakan penghapusan metode amortisasi goodwill dan mengharuskan pengujian penurunan nilai goodwill (impairment test) minimal sekali dalam setahun dan atau pada saat terdapat indikasi bahwa nilai goodwill mengalami penurunan. Pernyataan standar tersebut didasarkan pada argumen bahwa goodwill adalah aset yang memiliki masa manfaat tak terbatas sehingga metode amortisasi pada goodwill dianggap tidak sesuai.

Banyak argumen yang kontroversial terhadap pernyataan standar akuntansi tentang goodwill. Para pendukung pernyataan tersebut berargumen bahwa goodwill harus dikapitalisasi dan nilainya akan terus dipertahankan dari waktu ke waktu sehingga nilai goodwill tidak akan menurun. Jika goodwill diamortisasi maka akan terjadi perhitungan ganda, yaitu biaya mempertahankan nilai goodwill dan juga biaya amortisasi goodwill. Oleh sebab itu, goodwill tidak perlu diamortisasi. Namun, revaluasi secara berkala tetap perlu dilakukan untuk mengukur ada tidaknya penurunan nilai kapital dan pada kasus tersebut, jumlah penurunan nilai dibebankan kepada laba atau ekuitas. Selain itu, penentuan masa manfaat goodwill bukan perkara yang mudah karena adanya derajat ketidakpastian di masa datang yang sangat tinggi. Penentuan periode amortisasi seringkali dilakukan sewenang-wenang yang akan berimbas pada laba perusahaan (Radebaugh, 2002).

Pihak yang kontra berargumen bahwa goodwill tidak seharusnya dipertahankan karena goodwill tersebut akan terus digantikan dengan goodwill yang baru. Selain itu, tingkat kemampuan pemulihan nilai goodwill memiliki derajat ketidakpastian yang sangat tinggi. Goodwill adalah sumber daya yang akan 
digunakan oleh perusahaan, oleh karena itu harus dilakukan amortisasi yang akan mengurangi laba. Hal tersebut konsisten dengan konsep akuntansi akrual, yaitu konsep penandingan (matching principle). Goodwill dianggap sama dengan aset lainnya yang dikonsumsi dan digunakan untuk menghasilkan laba di masa depan. Jika goodwill tidak diamortisasi, maka laba di masa depan akan lebih saji (overstated) karena adanya biaya yang tidak dibebankan. (Radebaugh, 2002). Pembebanan jumlah amortisasi goodwill setiap tahun (hingga masa manfaat goodwill habis) akan sama dan relatif kecil sehingga tidak akan menimbulkan volatilitas laba yang dilaporkan (Jerman, 2008: 224).

Berbagai hasil penelitian (Jennings et. al, 2001; Moehrle, 2001; Churyk dan Chewning, 2003; Bugeja dan Gallery, 2006; Li dan meeks, 2006) telah menunjukkan bahwa amortisasi goodwill memiliki relevansi nilai. Namun, para penyusun standar memutuskan untuk tidak lagi mengamortisasi goodwill, dan perusahaan disyaratkan untuk melakukan pengujian penurunan nilai goodwill. Pengujian ini dapat menjadi lebih rumit ketika nilai pasar aktif untuk goodwill tidak tersedia. Kondisi tersebut kemudian dimanfaatkan oleh para manajer untuk melakukan pengujian secara subjektif. Selain itu, kerugian penurunan nilai goodwill terjadi secara tidak teratur setiap tahunnya dengan jumlah yang bervariasi, dan memungkinkan adanya jumlah nilai kerugian yang cukup besar sehingga dapat mengakibatkan volatilitas yang tinggi atas laba yang dilaporkan. Kerugian penurunan nilai dapat memberikan sinyal bahwa perusahaan akan mengalami kerugian atas nilai ekonomis masa depan dan memiliki efek yang signifikan terhadap aset dan pendapatan perusahaan (Jerman, 2008).

Teori keagenan (agency theory) dapat menjelaskan bagaimana perilaku manajer dalam menerapkan standar akuntansi dalam proses penyusunan laporan keuangannya. Asumsi dasar dalam teori keagenan adalah bahwa setiap individu, baik agen maupun prinsipal, akan berusaha memaksimalkan utilitasnya, dan mereka memiliki sumber daya serta inovasi untuk melaksanakan maksud tersebut (Schroeder et. al, 2011: 124). Sebagai agen yang mewakili prinsipal, manajer dipercaya untuk mengambil keputusan bisnis yang mewakili kepentingan pemegang saham (shareholders' best interest). Namun karena pemegang saham tidak dapat mengobservasi semua tindakan dan keputusan yang dibuat oleh agen, muncul suatu ancaman bahwa agen akan bertindak untuk memaksimalkan kesejahteraan pribadinya, bukan kesejahteraan pemegang saham (Schroeder et. al, 2011).

Perubahan standar akuntansi yang menghapuskan amortisasi goodwill dianggap memiliki sejumlah fleksibilitas dan celah yang dapat digunakan manajemen dalam melaporkan penurunan nilai goodwill dengan menggunakan pertimbangan sesuai kepentingan pribadinya. Kondisi tersebut diperkuat dengan tidak tersedianya nilai pasar goodwill yang jelas sehingga manajemen sebagai agen dapat memanfaatkannya untuk mengatur laba yang dilaporkan, yang dikenal sebagai manajemen laba. Jadi, masalah keagenan timbul ketika penilaian goodwill dilakukan berdasarkan insentif pribadi dan subjektivitas. Teori akuntansi positif (positive accounting theory) memprediksi bahwa manajer akan memilih prosedur akuntansi yang paling optimal berdasarkan insentif pribadi yaitu untuk memperoleh bonus, memenuhi kontrak hutang dan proses politik. Ketiga insentif tersebut dikenal sebagai perilaku oportunistik manajer (Belkaoui, 2004). 


\section{METODE PENELITIAN}

Untuk mendukung teori-teori tersebut, banyak penelitian telah menguji insentif manajer untuk melaporkan kerugian penurunan nilai goodwill, antara lain: Beaty dan Weber (2006), Lapointe (2006), Lala Guller (2006), Milena (2011), Jane dan Kati (2012), dan Majid (2013) menemukan bahwa: 1) pelaporan kerugian penurunan nilai goodwill cederung terjadi ketika perusahaan melakukan pergantian CEO, 2) pelaporan kerugian penurunan nilai goodwill dilakukan oleh manajer pada saat laba perusahaan terlalu rendah atau saat laba terlalu tinggi, 3) perusahaan yang berisiko melanggar kontrak hutang cenderung melaporkan kerugian penurunan nilai goodwill.

Pada umumnya penelitian-penelitian tersebut mendasarkan pada hipotesis kontrak bonus dan kontrak hutang. Hipotesis bonus menyatakan bahwa manajer akan menunda pelaporan kerugian penurunan nilai goodwill untuk meningkatkan laba periode tahun berjalan dengan tujuan untuk meningkatkan jumlah bonus yang dapat diterima manajer berdasarkan laba yang dihasilkan oleh perusahaan. Sementara itu, hipotesis kontrak utang menyatakan bahwa perusahaan dengan tingkat proporsi hutang terhadap ekuitas yang tinggi lebih cenderung menunda pelaporan kerugian penurunan nilai goodwil sehingga dapat meningkatkan jumlah laba yang dilaporkan dan menghindari biaya gagal bayar (default cost). Dengan motif bonus, manajer perusahaan dapat melakukan perataan laba atau big bath (Guller, 2006; Van de Poel, 2008; Lemans, 2012; Milena, 2012; Pajunen, dan Majid; 2013).

Berdasarkan hipotesis perataan laba (income smoothing), manajer akan mengakui kerugian penurunan nilai goodwill pada saat laba perusahaan cukup tinggi dengan tujuan untuk menjaga kestabilan tingkat laba atau mengurangi volatilitas laba yang dilaporkan. Hipotesis ini didukung oleh hasil penelitian Guller (2006) dan Van de Poel (2008) yang menunjukkan bahwa dan perusahaan yang melakukan perataan laba lebih cenderung melaporkan kerugian penurunan nilai goodwill dibandingkan dengan perusahaan yang melakukan big bath.

Big bath atau taking a bath merupakan suatu pola yang dilakukan oleh manajer ketika perusahaan berada pada kondisi tertekan, misalnya reorganisasi, termasuk mengganti CEO dan kinerja keuangannya yang memburuk dalam jangka panjang. Ketika perusahaan terpaksa harus melaporkan rugi, maka manajer akan melaporkan kerugian dalam jumlah yang lebih besar dengan cara melakukan penghapusan (write off) nilai aset secara besar-besaran. Penghapusan nilai aset tersebut akan memungkinkan perusahaan melaporkan kerugian yang lebih besar di tahun berjalan dan meningkatkan kemungkinan perusahaan untuk melaporkan laba di masa depan (Scott, 2003). Menurut hipotesis big bath, manajer yang tidak dapat memperoleh bonus pada tahun di mana kinerja keuangan perusahaan buruk akan melakukan big bath sehingga lebih memungkinkan bagi manajer untuk mendapatkan bonus di tahun depan. Oleh karena itu, perusahaan dengan strategi big bath akan mengakui kerugian penurunan nilai goodwill lebih awal untuk meningkatkan laba di masa datang (White et. al, 2003). Hasil penelitian terdahulu (Majid, 2013; Feist, 2013) menemukan bahwa perusahaan yang melakukan big bath cenderung melaporkan kerugian penurunan nilai goodwill.

Berdasarkan pembahasan tersebut, maka hipotesis penelitian yang berkaitan dengan variabel insentif pelaporan dengan motif bonus dalam pelaporan penurunan nilai goodwill adalah sebagai berikut: 
H1: $\quad$ Perusahaan yang melakukan big bath lebih cenderung melaporkan kerugian penurunan nilai goodwill dibandingkan perusahaan yang melakukan perataan laba

Dalam perspektif kontrak hutang, manajer akan menggunakan metode akuntansi tertentu untuk mempengaruhi perjanjian kontrak hutang perusahaan dengan krediturnya, sehingga manajer dapat membuat kinerja keuangan perusahaan seolah-olah dalam kondisi baik dengan tidak melaporkan kerugian penurunan nilai goodwill (Majid, 2013). Hipotesis kontrak hutang memprediksi bahwa perusahaan dengan tingkat proporsi hutang terhadap ekuitasnya yang tinggi akan memilih metode akuntansi yang meningkatkan laba, sehingga cenderung tidak melaporkan kerugian penurunan nilai goodwill. Hipotesis tersebut didukung oleh hasil penelitian terdahulu (Beaty dan Weber, 2006; Ramanna dan Watts, 2011; Feist, 2013) yang menunjukkan adanya korelasi negatif antara kontrak hutang (debt covenant) dan probabilitas pelaporan kerugian penurunan nilai goodwill.

$\mathrm{H} 2$ : Perusahaan yang memiliki tingkat leverage yang tinggi lebih cenderung tidak melaporkan kerugian penurunan nilai goodwill

Penelitian Van de Poel (2008) memasukkan varibel kualitas auditor dalam menguji pengaruh insentif pelaporan terhadap pelaporan kerugian penurunan nilai goodwill. Hasilnya menunjukkan bahwa ketika insentif pelaporan perataan laba rendah, perusahaan yang diaudit oleh KAP Big 4 akan lebih cenderung mengakui kerugian penurunan nilai goodwill yang lebih besar dibandingkan dengan perusahaan yang diaudit oleh KAP non Big 4. Hal ini didasarkan pada argumen bahwa KAP dengan kualitas audit yang lebih tinggi memiliki kemampuan dan independensi untuk menentukan penurunan nilai goodwill dan memaksa perusahaan untuk melaporkan kerugian penurunan nilai tersebut.

H3: Perusahaan yang diaudit oleh KAP Big 4 lebih cenderung melaporkan kerugian penurunan nilai goodwildibandingkan dengan perusahaan yang diaudit oleh KAP non BIG4

Kinerja keuangan perusahaan merupakan salah satu faktor penting yang menjadi pertimbangan manajer untuk melaporkan penurunan nilai goodwill. Perusahaan yang melaporkan kerugian penurunan nilai goodwill cenderung memiliki tingkat penjualan, arus kas dan return on assets yang rendah (Guller, 2006; Van de Poel, 2008, Majid, 2013, Feist, 2013). Namun untuk perusahaan dengan nilai goodwill yang lebih tinggi dibanding nilai aset lainnya cenderung melaporkan kerugian penurunan nilai goodwill (Ghazaleh, 2011; Ramanna dan Watts, 2012; Majid, 2013).

H4a: Perusahaan dengan tingkat penjualan yang lebih rendah cenderung melaporkan kerugian penurunan nilai

H4b: Perusahaan dengan perubahan ROA yang lebih rendah cenderung melaporkan kerugian penurunan nilai goodwill 
H4c: Perusahaan yang memiliki nilai goodwill yang lebih tinggi cenderung melaporkan kerugian penurunan nilai goodwill

Teori persinyalan (signalling theory) menekankan kepada pentingnya informasi yang dikeluarkan oleh perusahaan terhadap keputusan investasi pihak di luar perusahaan. Informasi merupakan unsur penting bagi pemegang saham dan pelaku bisnis lainnya karena pada waktu informasi diumumkan dan semua pelaku pasar sudah menerima informasi tersebut, pelaku pasar terlebih dahulu menginterpretasikan dan menganalisis informasi tersebut sebagai signal baik (good news) atau sinyal buruk (bad news). Sinyal yang disampaikan melalui laporan keuangan perusahaan menjadi pertimbangan penting bagi investor dalam pengambilan keputusan investasinya. Jika informasi dalam laporan keuangan yang dipublikasikan tersebut dinilai memberikan sinyal yang baik, maka investor akan memberikan respon positif atas sinyal tersebut. (Sharpe, 1997; Ivana, 2005).

Informasi kerugian penurunan nilai goodwill yang dilaporkan perusahaan memberikan sinyal kepada pemegang saham bahwa kemungkinan arus kas masa depan perusahaan akan menurun sehingga akan berpengaruh kepada kemampuan perusahaan untuk menghasilkan keuntungan di masa depan, sehingga akan mempengaruhi pembagian dividen. Dengan demikian, kerugian penurunan nilai goodwill yang dilaporkan perusahaan dipandang memberikan informasi tentang prospek perusahaan yang kurang baik di masa depan (bad news). Hipotesis tersebut didukung oleh hasil penelitian terdahulu (Lapointe, 2008; Abu Ghazaleh et al, 2012; Zadeh et al, 2013) yang menunjukkan adanya korelasi negatif antara kerugian penurunan nilai goodwill dan nilai perusahaan.

H5: Kerugian penurunan nilai goodwill berpengaruh negatif terhadap nilai pasar perusahaan

Objek penelitian ini adalah pelaporan goodwill, insentif pelaporan, kinerja keuangan, kualitas auditor, dan nilai pasar perusahaan-perusahaan yang terdaftar di Bursa Efek Indonesia (BEI) selama periode 2010-2012.

\section{Operasionalisasi Variabel}

Untuk menguji hipotesis yang diajukan, penelitian ini menggunakan dua model penelitian. Model 1 merupakan model regresi untuk menguji faktor-faktor yang mempengaruhi pelaporan kerugian penurunan nilai goodwill perusahaan. Variabel dependen dalam model ini adalah pelaporan kerugian penurunan nilai goodwill yang dilaporkan perusahaan, menggunakan dummy variable konsisten dengan yang digunakan oleh Milena (2012) dan Guler (2006), yaitu nilai 1 untuk perusahaan yang melaporkan kerugian penurunan nilai goodwill, dan nilai 0 untuk sebaliknya. Variabel independennya terdiri dari: 1) insentif pelaporan, 2) kinerja keuangan perusahaan, dan 3) kualitas auditor. Variabel-variabel tersebut dijelaskan sebagai berikut:

1) Insentif pelaporan, dilihat dari dua persfektif yaitu motif bonus dan kontrak hutang. Motif bonus dibagi menjadi dua yaitu perataan laba (income smoothing) dan big bath yang diukur berdasarkan nilai unexpected operating return on-assets (UOROA) dengan rumus sebagai berikut:

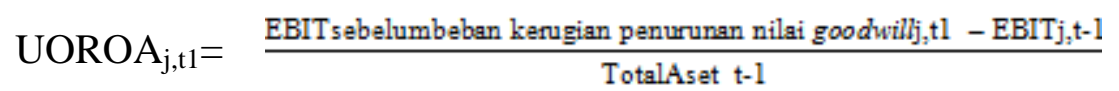


Jika nilai UOROA > 0 maka perusahaan melakukan perataan laba, sebaliknya jika nilai UOROA $<0$ maka perusahaan melakukan big bath. Pengukuran variabel ini menggunakan variabel dummy, di mana nilai 1 untuk perusahaan yang melakukan big bath dan 0 untuk perusahaan yang melakukan perataan laba (Milena, 2012 ; Guler, 2006).

Berdasarkan hipotesis kontrak hutang, insentif pelaporan juga dapat dipengaruhi oleh debt covenant. Konsisten dengan penelitian terdahulu (Beaty dan Weber, 2006; Guller, 2006; Milena, 2012, dan Majid, 2013), pengukuran kontrak hutang menggunakan tingkat leverage perusahaan, yaitu total utang dibagi total ekuitas.

2) Kualitas Auditor diukur dengan menggunakan variabel dummy yaitu nilai 1 jika perusahaan diaudit oleh KAP Big 4 dan 0 jika perusahaan diaudit oleh KAP Non-Big 4.

3) Kinerja keuangan, kosisten dengan para peneliti terdahulu (Majid, 2013; AbuGhazaleh (2011), untuk variabel kinerja keuangan diukur dengan menggunakan: a) perubahan penjualan untuk menangkap atribut kinerja akrual terkait, b) return on assets (ROA), dan c) nilai goodwill yang dilaporkan.

Model 2 bertujuan untuk menguji pengaruh kerugian penurunan nilai goodwill terhadap nilai perusahaan. Variabel dependen dalam model penelitian ini mengacu kepada penelitian Chambers (2007) yaitu nilai pasar saham perusahaan yang diukur selama tiga bulan sejak perusahaan menerbitkan laporan keuangan. Variabel independen pada model ini adalah beban kerugian penurunan nilai goodwill yang dilaporkan perusahaan .

\section{Data dan Sampel}

Data penelitian ini sepenuhnya adalah data sekunder (secondary data), yaitu data beban kerugian penurunan nilai goodwill, nilai buku akun-akun perusahaan, rasio-rasio keuangan perusahaan yang diperoleh dari laporan keuangan emiten untuk tahun 2010-2012, dan data harga pasar saham yang diperoleh melalui http:// yahoo.finance.com.

Standar akuntansi yang berlaku berkaitan dengan goodwill (PSAK 19, PSAK 22, dan PSAK 48) berlaku efektif pada 1 Januari 2011. Perusahaanperusahaan yang diamati dalam penelitian ini adalah perusahaan-perusahaan yang terdaftar di BEI yang melaporkan goodwill selama periode 2010 dan 2012. Pemilihan sampel dalam penelitian ini dilakukan dengan menggunakan metode nonprobability sampling yaitu purposive sampling. Perusahaan sampel adalah perusahaan yang memenuhi kriteria sebagai berikut: 1)Perusahaan yang menerbitkan laporan keuangan yang berakhir per 31 Desember dan telah diaudit; 2)Mempunyai data yang lengkap untuk pengukuran seluruh variabel. Data yang dimaksud adalah informasi yang tercakup dalam neraca, laporan arus kas, laporan laba/ rugi komprehensif, catatan atas laporan keuangan, serta data harga pasar saham.

Perusahaan yang memenuhi kriteria tersebut diperoleh sebanyak 52 perusahaan sampel selama periode 2010-2012. Prosedur pemilihan sampel penelitian dapat dilihat pada Tabel 1 . 
Tabel 1

Prosedur Pemilihan Sampel

\begin{tabular}{lc}
\hline \multicolumn{1}{c}{ Keterangan } & Jumlah \\
\hline Perusahaan publik yang terdaftar di BEI dan menerbitkan & 71 \\
laporan keuangan yang diaudit pada periode 2010-2012 & \\
Dikurangi: & \\
Perusahaan yang menerbitkan laporan keuangan dengan & 14 \\
mata uang selain Rupiah & 5 \\
Perusahaan yang tidak memiliki data lengkap & 52
\end{tabular}

Sumber: Hasil pengolahan data.

\section{Pengujian Hipotesis}

Untuk menguji pengaruh insentif pelaporan, kinerja keuangan, dan kualitas auditor terhadap pelaporan kerugian penurunan nilai goodwill, digunakan persamaan regresi logistik dengan formula sebagai berikut:

$$
\operatorname{Ln}\left(\frac{p}{p-1}\right)=\beta_{0}+\beta_{1} \text { bath }+\beta_{2} \text { lev }+\beta_{3} \text { big } 4+\beta_{4} \text { sales }+\beta_{5} \text { ROA }+\beta_{6} \text { goodwill }+
$$

$\boldsymbol{\varepsilon}$

dimana:

$\mathrm{p} \quad=$ Probabilitas pelaporan kerugian penurunan nilai goodwill. Variabel dummy, yaitu nilai 1 untuk perusahaan yang melaporkan kerugian penurunan nilai goodwill pada tahun t, 0 untuk perusahaan yang tidak melaporkan kerugian penurunan nilai goodwill pada tahun $\mathrm{t}$

Bath = big bath. Variabel dummy, yaitu nilai 1 untuk perusahaan yang melakukan big bath dan 0 untuk perusahaan yang melakukan perataan laba pada tahun $\mathrm{t}$.

Lev $=$ Leverage adalah total liabilitas dibagi ekuitas pada $\mathrm{t}-1$

Big $4=$ Kualitas auditor. Variabel dummy, yaitu nilai 1 untuk perusahaan yang diaudit oleh KAP Big 4, dan 0 untuk perusahaan yang diaudit oleh KAP Non-Big 4 pada tahun t.

Sales $\quad=$ Perubahan penjualan di skala dengan total aset $\mathrm{t}-1$.

ROA $=$ Perubahan return on assets pada tahun $\mathrm{t}$.

Goodwill $=$ Saldo goodwill per total asset pada $\mathrm{t}-1$ 
Model 2 dalam penelitian ini adalah untuk menguji pengaruh kerugian penurunan nilai goodwill terhadap nilai perusahaan, digunakan persamaan regresi linier sederhana sebagai berikut:

dimana:

$$
\mathrm{MVE}_{\mathrm{t}}=\theta_{0}+\theta_{1} \mathrm{IMP}+\varepsilon
$$

MVE = Market value of equity yaitu nilai pasar saham perusahaan selama tiga bulan sejak tanggal penerbitan laporan keuangan untuk tahun $\mathrm{t}$.

IMP = Goodwill impairment yaitu kerugian penurunan nilai goodwill yang dilaporkan perusahaan untuk tahun $\mathrm{t}$.

\section{HASIL DAN PEMBAHASAN}

Hasil analisis deskriptif variabel penelitian menunjukkan bahwa pada tahun 2011, yakni tahun dimana standar akuntansi berkaitan dengan goodwill baru saja berlaku efektif di Indonesia, dari total 52 perusahaan sampel (berdasarkan purposive judgement sampling) terdapat 14 perusahaan yang melaporkan kerugian penurunan nilai goodwill, sedangkan sisanya yaitu sebanyak 38 perusahaan tidak melaporkan kerugian penurunan nilai goodwill. Pada tahun 2012, jumlah perusahaan yang melaporkan kerugian penurunan nilai goodwill berkurang menjadi 8 perusahaan, sedangkan 44 perusahaan tidak melaporkan kerugian penurunan nilai goodwill. Perusahaan yang melaporkan kerugian penurunan nilai goodwill lebih banyak melakukan perataan laba, yaitu 10 perusahaan di tahun 2011 dan 7 perusahaan di tahun 2012, sedangkan perusahaan yang melakukan big bath sebanyak 4 perusahaan di tahun 2011 dan hanya 1 perusahaan di tahun 2012.

Nilai rata-rata leverage perusahaan yang melaporkan kerugian penurunan nilai goodwill pada tahun 2011 adalah sebesar 0,541, lebih tinggi dari nilai ratarata leverage perusahaan yang tidak melaporkan kerugian penurunan nilai goodwill yaitu 0,467. Kondisi yang sama juga ditunjukkan pada tahun 2012 dimana nilai rata-rata leverage perusahaan yang melaporkan kerugian penurunan nilai goodwill dan yang tidak melaporkan kerugian penurunan nilai goodwill masing-masing sebesar 0,567 dan 0,472.

Jika melihat perbandingan perubahan penjualan, perusahaan yang melaporkan kerugian penurunan nilai goodwill memiliki nilai rata-rata perubahan penjualan yang jauh lebih rendah dibandingkan dengan perusahaan yang tidak melaporkan kerugian penurunan nilai goodwill. Perubahan penjualan perusahaan yang melaporkan kerugian penurunan nilai goodwill pada tahun 2011 adan 2012 adalah masing-masing sebesar 0,009 dan 0,051 sementara perusahaan yang tidak melaporkan kerugian penurunan nilai goodwill memiliki perubahan penjualan yang lebih tinggi yaitu sebesar 0,148 pada tahun 2011 dan 0,125 pada tahun 2012 .

Pada tahun 2011, rata-rata perubahan return on asset (ROA) perusahaan yang melaporkan kerugian penurunan nilai terlihat negatif yakni sebesar $-1,017$ sementara rata-rata perubahan return on asset perusahaan yang tidak melaporkan kerugian penurunan nilai goodwill menunjukkan angka positif sebesar 0,369. Sementara itu, pada tahun 2012 rata-rata perubahan ROA perusahaan yang melaporkan kerugian penurunan nilai goodwill adalah sebesar 0,553, lebih tinggi dari rata-rata perubahan ROA perusahaan yang tidak melaporkan kerugian penrunan nilai goodwill yang hanya sebesar 0,467. 
Nilai rata-rata goodwill per total aset perusahaan yang melaporkan kerugian penurunan nilai goodwill baik pada tahun 2011 dan 2012 lebih tinggi dibandingkan dengan nilai rata-rata goodwill per total aset perusahaan yang tidak melaporkan kerugian penurunan nilai goodwill. Nilai rata-rata goodwill perusahaan yang melaporkan kerugian penurunan nilai goodwill adalah sebesar 0,081 dan 0,056 masing-masing untuk tahun 2011 dan 2012 sedangkan nilai goodwill per total aset untuk perusahaan yang tidak melaporkan kerugian penurunan nilai goodwill pada tahun 2011 dan 2012 masing-masing hanya sebesar 0,037 dan 0,042 .

Tabel 2

Hasil Uji Kemampuran Prediksi Model

Classification Table ${ }^{\mathrm{a}} 2011$

\begin{tabular}{|c|c|c|c|c|c|}
\hline \multicolumn{3}{|c|}{ Observed } & \multicolumn{3}{|c|}{ Predicted } \\
\hline & & & \multicolumn{2}{|c|}{ Gw_Imp } & \multirow{2}{*}{$\begin{array}{c}\text { Percentage } \\
\text { Correct }\end{array}$} \\
\hline & & & Tidak Melaporkan & Melaporkan & \\
\hline \multirow{4}{*}{$\begin{array}{l}\text { Ste } \\
p 1\end{array}$} & Gw_Imp & Tidak & 37 & 1 & 97,4 \\
\hline & & Melaporkan & & & \\
\hline & & Melaporkan & 13 & 1 & 7,1 \\
\hline & Overall 1 & ercentage & & & 73,1 \\
\hline
\end{tabular}

Classification Table 2012

\begin{tabular}{|c|c|c|c|c|}
\hline & \multirow[t]{3}{*}{ Observed } & \multicolumn{3}{|c|}{ Predicted } \\
\hline & & \multicolumn{2}{|c|}{ Gw_Imp } & \multirow{2}{*}{$\begin{array}{c}\text { Percentage } \\
\text { Correct }\end{array}$} \\
\hline & & Tidak Melaporkan & Melaporkan & \\
\hline \multirow[t]{4}{*}{ Step 1} & Gw_Imp Tidak & 41 & 3 & 93,2 \\
\hline & Melaporkan & & & \\
\hline & Melaporkan & 3 & 5 & 62,5 \\
\hline & Overall Percentage & & & 88,5 \\
\hline
\end{tabular}

Sumber: Hasil pengolahan data.

Tabel 2 menunjukkan kemampuan prediksi model regresi logistik, yaitu untuk memprediksi probabilitas perusahaan melaporkan kerugian penurunan nilai goodwill. Untuk tahun 2011, model regresi yang digunakan memiliki nilai prediksi sebesar 73,1 persen. Kemampuan prediksi model tersebut lebih rendah dibandingkan dengan kemampuan prediksi model untuk tahun 2012 yaitu sebesar 88,5 persen.

Tabel 3

Hasil Uji Koefisien Determinasi

\begin{tabular}{cccc}
\hline \multicolumn{4}{c}{ Model Summary 2011 } \\
\hline Step & $\begin{array}{c}\text {-2 Log } \\
\text { likelihood }\end{array}$ & $\begin{array}{c}\text { Cox \& Snell } \\
\text { R Square }\end{array}$ & $\begin{array}{c}\text { Nagelkerke R } \\
\text { Square }\end{array}$ \\
\hline 1 & $55,814^{\text {a }}$ &, 088 &, 127 \\
\hline \multicolumn{4}{c}{} \\
& & \\
& Model Summary 2012 &
\end{tabular}




\begin{tabular}{lrrr}
\hline Step & $\begin{array}{c}-2 \mathrm{Log} \\
\text { likelihood }\end{array}$ & $\begin{array}{c}\text { Cox \& Snell } \\
\text { R Square }\end{array}$ & $\begin{array}{c}\text { Nagelkerke } R \\
\text { Square }\end{array}$ \\
\hline 1 & $21,715^{\mathrm{a}}$ &, 357 &, 619 \\
\hline
\end{tabular}

Sumber: Hasil pengolahan data.

Nilai Nagelkerke's $R$ Square (Tabel 3) memberi gambaran bahwa variabilitas pelaporan kerugian penurunan nilai goodwill dapat dijelaskan oleh variabilitas insentif pelaporan, kinerja keuangan, dan kualitas auditor. Nilai koefisien determinasi ( $R$ Square) untuk tahun 2011 sebesar 12,7\% lebih rendah dibandingkan tahun 2012 sebesar 0,619. Hal ini menunjukkan bahwa variabel insentif pelaporan, kinerja keuangan, dan kualitas auditor lebih dapat menjelaskan variabilitas pelaporan kerugian penurunan nilai goodwill pada tahun 2012 dibandingkan tahun 2011.

\section{Tabel 4}

\section{Hasil Uji Keberartian Model}

\begin{tabular}{lrrrr}
\hline \multicolumn{4}{c}{ Hosmer and Lemeshow Test 2011} \\
\hline Step & Chi-square & Df & & Sig. \\
\hline 1 & 6,795 & 8 &, 559 \\
\hline
\end{tabular}

\begin{tabular}{lrrrr}
\multicolumn{4}{c}{ Hosmer and Lemeshow Test 2012} \\
\hline Step & Chi-square & Df & Sig. \\
\hline 1 & 4,913 & 8 &, 767 \\
\hline \multicolumn{4}{c}{ Sumber: Hasil pengolahan data. }
\end{tabular}

Hasil uji keberartian model (Tabel 4) menunjukkan nilai Chi-Square 6,795 untuk 2011 dan 4,913 untuk 2012 lebih rendah dari nilai Chi-Square tabel (nilai Chi-Square tabel untuk df 8 dengan tingkat signifikansi 0,05 adalah sebesar 15,507). Demikian juga nilai signifikansi 0,559 untuk tahun 2011 dan 0,767 lebih tinggi dari 0,05. Hasil ini menunjukkan bahwa model regresi logistik (model 1) dapat digunakan baik untuk periode 2011 maupun 2012.

\section{Tabel 5}

Ringkasan Hasil Uji Regresi Logistik (Model 1)

\begin{tabular}{lccccc}
\hline \multirow{2}{*}{ Variabel } & \multirow{2}{*}{$\begin{array}{c}\text { Arah } \\
\text { Prediksi }\end{array}$} & \multicolumn{2}{c}{2011} & \multicolumn{2}{c}{2012} \\
\cline { 3 - 6 } Bath & + & $-0,002$ &, 998 & $-6,506$ &, $098^{*}$ \\
\hline Leverage & - & 0,615 &, 590 & 3,156 &, 178 \\
\hline Sales & - & 0,380 &, 758 & $-13,39$ &, $042^{* *}$ \\
\hline ROA & - & $-0,282$ &, 385 & 1,276 &, $015^{* *}$ \\
\hline Goodwill & + & 3,648 &, 381 & 23,53 &, $083^{*}$ \\
\hline BIG4 & + & 0,494 &, 515 & 2,689 &, $067^{*}$ \\
\hline \multicolumn{5}{r}{ * Signifikan pada tingkat $10 \%$, ** $^{*}$ pada tingkat $5 \%$} \\
\end{tabular}

Hasil pengujian pengaruh variabel independen terhadap variabel dependen (Tabel 5) menunjukkan bahwa big bath, perubahan penjualan, ROA, nilai goodwill, dan KAP Big 4 berpengaruh signifikan terhadap kecenderungan perusahaan melaporkan kerugian penurunan nilai goodwill (pada tingkat signifikansi 5\% dan 10\%). Pengaruh signifikan ini hanya terjadi pada tahun 2012, 
tidak ditemukan pengaruh yang signifikan dari masing-masing variabel tersebut secara individual pada tahun 2011. Penjelasan tidak ditemukannya pengaruh yang signifikan di tahun 2011 kemungkinan karena standar akuntansi yang mensyaratkan perusahaan untuk melakukan pengujian penurunan nilai goodwill dan melaporkan kerugian penurunan nilai goodwill (PSAK yang terkait dengan goodwill) baru berlaku efektif awal tahun 2011. Dalam penerapan standar yang baru berlaku tersebut, manajemen perlu beradaptasi dan perlu pengetahuan yang lebih luas dalam pengujian penurunan nilai goodwill. Oleh karena pada tahun 2011 tidak ditemukan signifikansi masing-masing variabel depeden, maka berikut ini dibahas pengaruh masing-masing variabel tersebut untuk periode 2012: (1) Hasil pengujian menunjukkan bahwa insentif big bath berpengaruh negatif terhadap kecenderungan perusahaan untuk melaporkan kerugian penurunan nilai goodwill. Pengaruh negatif tersebut berlawanan dengan hipotesis yang diajukan, dan dapat diartikan bahwa perusahaan yang melakukan perataan laba lebih cenderung melaporkan kerugian penurunan nilai goodwill dibandingkan dengan perusahaan yang melakukan big bath. Hasil penelitian ini konsisten dengan hasil penelitian hasil penelitian Guller (2006) dan Van de Poel (2008) yang menunjukkan bahwa dan perusahaan yang melakukan perataan laba lebih cenderung melaporkan kerugian penurunan nilai goodwill dibandingkan dengan perusahaan yang melakukan big bath. Hasil ini juga mendukung income smoothing hypotesis yang menyatakan bahwa pada saat laba perusahaan cukup tinggi, manajer akan mengakui kerugian penurunan nilai goodwill dengan tujuan untuk menjaga kestabilan tingkat laba atau mengurangi volatilitas laba, sehingga laba yang dilaporkan akan terlihat tidak berfluktuasi dan cederung bertumbuh dari waktu ke waktu; (2)Berdasarkan hasil pengujian kontrak hutang, penelitian ini tidak berhasil memperoleh bukti bahwa leverage berpengaruh terhadap kecenderungan perusahaan untuk melaporkan kerugian penurunan nilai goodwill. Salah satu penyebab tidak diperolehnya cukup bukti tersebut, kemungkinannya adalah karena proksi kontrak hutang yang digunakan, yakni leverage, tidak dapat menangkap risiko tidak terbayarnya utang perusahaan, kemungkinan pengukuran lainnya, misalnya tingkat kesulitan keuangan perusahaan, lebih dapat menjelaskan probabilitas pelaporan penurunan nilai goodwill. Hal ini konsisten dengan temuan Li (2009) dan Abdul Majid (2013) yang tidak berhasil mendukung hipotesis kontrak hutang. Hasil ini juga tidak dapat mendukung hasil penelitian terdahulu (Beaty dan Weber, 2006; Ramanna dan Watts, 2011; Feist, 2013) yang berhasil memperoleh bukti adanya korelasi negatif antara kontrak hutang (debt covenant) dan probabilitas pelaporan kerugian penurunan nilai goodwill; (3) Hasil pengujian atas kinerja keuangan perusahaan menunjukkan bahwa perubahan penjualan, ROA dan nilai goodwill berpengaruh signifikan terhadap kecenderungan perusahaan untuk melaporkan kerugian penurunan nilai goodwill. Namun dari ketiga ukuran kinerja tersebut, hanya perubahan penjualan dan nilai goodwill memiliki arah sesuai prediksi, sedangkan ROA berpengaruh positif terhadap kecenderungan pelaporan kerugian penurunan goodwill, tidak sesuai dengan arah prediksi. Hal ini konsisten dengan hasil pengujian hipotesis 1 bahwa perusahaan cenderung menggunakan strategi perataan laba sebagai insentif untuk melaporkan penurunan nilai goodwill, sehingga perusahaan yang memiliki tingkat ROA yang lebih besar akan cederung melaporkan kerugian penurunan nilai goodwill. 
Hasil penelitian menunjukkan bahwa perubahan penjualan berpengaruh negatif terhadap kecenderungan perusahaan untuk melaporkan kerugian penurunan nilai goodwill. Perusahaan yang memiliki perubahan penjualan yang rendah lebih cenderung melaporkan kerugian penurunan nilai goodwill. Hasil penelitian ini konsisten dengan hipotesis penelitian yang diajukan dan teori akuntansi positif yang menyatakan bahwa perusahaan dengan kinerja yang lebih buruk akan berpengaruh terhadap kemampuannya menghasilkan arus kas masuk di masa depan dan akan cenderung melaporkan kerugian penurunan nilai goodwill. Hasil penelitian ini juga mendukung hasil penelitian Guller (2006) dan Abdul Majid (2013) yang menunjukkan adanya korelasi negatif antara perubahan penjualan dan pelaporan kerugian penurunan nilai goodwil.

Hasil pengujian menunjukkan adanya korelasi positif antara ROA pelaporan kerugian penurunan nilai goodwill, yang artinya bahwa perusahaan dengan kemampuan dalam menghasilkan laba yang lebih tinggi cenderung melaporkan kerugian penurunan nilai goodwill. Hasil pengujian tersebut bertentangan hipotesis yang diajukan dan beberapa hasil penelitian terdahulu (Guller, 2006; Van de Poel, 2008; Pajunen, 2012; Feist, 2013) yang menyatakan bahwa perubahan ROA berpengaruh negatif terhadap kecenderungan perusahaan dalam melaporkan kerugian penurunan nilai goodwill, atau dengan kata lain semakin tinggi perubahan ROA, semakin rendah kecenderungan untuk melaporkan kerugian penurunan nilai goodwill. Perusahaan-perusahaan yang memiliki kinerja keuangan yang lebih rendah cenderung tidak menginginkan kinerja keuangannya menjadi lebih buruk dengan melaporkan kerugian penurunan nilai goodwill. Hal tersebut didukung oleh data statistik atas sampel perusahaan dalam penelitian ini yang menunjukkan bahwa perusahaan yang melaporkan kerugian penurunan nilai goodwill memiliki ROA yang lebih tinggi dibandingkan dengan perusahaan yang tidak melaporkan kerugian penurunan nilai goodwill.

Pengujian pengaruh goodwill menunjukkan korelasi positif antara goodwill dan pelaporan kerugian penurunan Nilai goodwill. Hasil tersebut konsisten dengan hipotesis penelitian yang diajukan dan hasil penelitian terdahulu (Guller, 2006 dan Abdul Majid, 2013) yang menyatakan bahwa perusahaan yang memiliki nilai goodwill yang tinggi lebih cenderung melaporkan kerugian penurunan nilai goodwill dengan tujuan untuk menunjukkan nilai aset terbesarnya adalah goodwill yang mampu memberikan kinerja operasi yang lebih tinggi dibanding aset lainnya.

Hasil pengujian kualitas auditor, hasil penelitian menunjukkan bahwa perusahaan yang diaudit oleh KAP Big 4 lebih cenderung melaporkan kerugian penurunan nilai goodwill. Hasil ini konsisten dengan hipotesis yang diajukan dan mendukung hasil penelitian Van de Poel (2008) yang menyatakan bahwa perusahaan yang diaudit oleh auditor Big 4 cendrung melaporkan penurunan nilai goodwill dibanding non-Big 4, hal ini mengindikasikan bahwa auditor non-Big 4 memberi keleluasaan bagi perusahaan untuk memilih kebijakan akuntansinya yang dapat meningkatkan laba yang dilaporkan dengan cara menunda pelaporan kerugian penurunan nilai goodwill. Argumen alternatif untuk menjelaskan hasil ini konsisten dengan yang dikemukakan oleh Wooten (2003) bahwa KAP big 4 dianggap memiliki kompetensi dan independensi yang lebih tinggi untuk menemukan kecurangan-kecurangan atau salah saji yang material dalam pelaporan keuangan perusahaan. Dengan kompetensi dan independensinya, 
auditor dapat memaksa perusahaan untuk mengikuti standar akuntansi yang berlaku untuk goodwill dengan menjelaskan asumsi-asumsi kondisi-kondisi yang sebenarnya yang mendasari terjadinya penurunan nilai goodwill.

\section{Tabel 7 \\ Hasil Uji Regresi Liniar Sederhana (Model 2)}

\begin{tabular}{|l|l|r|r|c|}
\multicolumn{7}{|c|}{ Model Summary } \\
\hline Model & $\mathrm{R}$ & R Square & $\begin{array}{c}\text { Adjusted R } \\
\text { Square }\end{array}$ & $\begin{array}{c}\text { Std. Error of } \\
\text { the Estimate }\end{array}$ \\
\hline 1 &, $282^{\mathrm{a}}$ &, 079 &, 070 & $1,031413 \mathrm{E} 4$ \\
\hline
\end{tabular}

a. Predictors: (Constant), IMP

\begin{tabular}{|c|c|c|c|c|c|}
\hline \multicolumn{6}{|c|}{ Coefficients $^{\mathrm{a}}$} \\
\hline \multirow[t]{2}{*}{ Model } & Unstan & lardized & Standardized & \multirow[b]{2}{*}{$\mathrm{t}$} & \multirow[b]{2}{*}{ Sig. } \\
\hline & $\mathrm{B}$ & Std. Error & Beta & & \\
\hline (Constant) & 3796,566 & 1060,446 & & 3,580 &, 001 \\
\hline IMP & ,000 &, 000 &,- 282 & $-2,908$ & ,004 \\
\hline
\end{tabular}

a. Dependent Variable: MVE

Hasil pengujian Model 2 (Tabel 7) menunjukkan nilai $R$ Square 0,079 dan nilai signifikansi 0,004 dengan koefisien beta $-0,282$. Hal ini menunjukan bahwa kerugian penurunan nilai goodwill berpengaruh negatif terhadap nilai pasar saham perusahaan. Hasil ini konsisten dengan hipotesis yang diajukan dan mendukung hasil penelitian terdahulu (Lapointe, 2008; Abu Ghazaleh et al, 2012; Zadeh et al, 2013) yang menunjukkan adanya korelasi negatif antara kerugian penurunan nilai goodwill dan nilai perusahaan. Informasi kerugian penurunan nilai goodwill yang dilaporkan perusahaan dipandang sebagai sinyal yang buruk (bad news). Para pemegang saham memandang informasi memberi sinyal adanya penurunan arus kas dan kemampuan perusahaan untuk menghasilkan keuntungan di masa depan sehingga tidak menguntungkan nilai investasinya.

\section{SIMPULAN DAN SARAN Simpulan}

Berdasarkan pembahasan yang diuraikan di atas, hasil penelitian dapat disimpulkan sebagai berikut: 1) Isentif perataan laba lebih memicu manajer untuk melaporkan kerugian penurunan nilai goodwill dibandingkan insentif big bath;2) Tingkat leverage tidak terbukti mempengaruhi kecenderungan perusahaan melaporkan kerugian penurunan nilai goodwill. Perusahaan dengan perubahan penjualan yang rendah lebih cenderung melaporkan kerugian penurunan nilai goodwill; 3) Perusahaan dengan perubahan ROA dan nilai goodwill yang tinggi lebih cenderung melaporkan kerugian penurunan nilai goodwill; 4) Kerugian penurunan nilai goodwill yang dilaporkan perusahaan dipandang sebagai sinyal buruk sehingga berpengaruh negatif terhadap nilai perusahaan.

\section{Saran}

Penelitian ini memiliki beberapa keterbatasan dalam periode amatan yang sangat pendek, yaitu tahun 2011 dan 2011, karena penerapan standar yang 
berkaitan dengan goodwill, khususnya standar yang mengharuskan perusahaan pengujian penurunan nilai goodwill baru efektif sejak awal tahun 2011. Selain itu, proksi-proksi yang digunakan juga mengacu pada salah satu pengukuran yang mungkin kurang tepat untuk mengukur variabel penelitian. Misalnya, penelitian ini yang hanya menggunakan leverage untuk mengukur kontrak hutang sehingga tidak dapat menangkap informasi biaya gagal bayar perusahaan sepenuhnya. Oleh sebab itu, untuk penelitian sejenis disarankan untuk dapat memperpanjang periode amatan serta menggunakan faktor-faktor ekonomi lainnya seperti ROA industri, financial distress, serta struktur kepemilikan, dan pergantian CEO untuk lebih dapat menjelaskan kecenderungan perusahaan untuk melaporkan kerugian penurunan nilai goodwill.

\section{DAFTAR PUSTAKA}

Abdul Majid, Jamaliah. 2013. "Accounting Choices Relating to Goodwill Impairment: Evidence from Malaysia". PhD thesis, University of Glasgow.

Abu Ghazaleh, Naser M. et. al.2012. International Journal of Economics and Finance "The Value Relevance of Goodwill Impairments: UK Evidence". Vol. 4 No.4 pp 206-216.

Belkaoui, Ahmed- Riahi. 2004. "Accounting Theory”. Edisi 5. London: Thomson Learning.

Brutting, Milena 2011. "Goodwill Impairment Causes and Impacts”. Thesis. Sir John Cass Business School, City University London.

Chambers, Dennis J. 2007. Working Paper "Has Accounting under SFAS 142 Improved Financial Reporting?" Kennesaw State University.

Chen, Changlin et. al.. 2004. Goodwill Valuation Effects of The Initial Adoption of SFAS 142. Social Science Research Network

Feist, Karin. 2013. Working Paper "Determinants of Goodwill Write-Offs: The Role of New Sentiments". University Frankfurt Germany.

Financial Accounting Standards Board. 2001. "Statement of Financial Accounting Standard. Per June 2001”. Connecticut: Financial Accounting Standards Board.

Guler, Lale. 2006. "Goodwill Impairment Charges under SFAS 142: Role of Executive's Incentives and Corporate Governance". Ph.D dissertation Texas A\&M University

Ikatan Akuntan Indonesia. 2012. “Standar Akuntansi Keuangan Per 1 Juni 2012”. Jakarta: Ikatan Akuntan Indonesia.

International Accounting Standard Board. 2012. "International Accounting Standard No. 36: Impairment of Assets". UK. International Accounting Standards Board.

Jarva, Henry. 2009. Journal of Business Finance and Accounting "Do Firms Manage Fair Value Estimates? An Examination of SFAS 142 Goodwill Impairment". Vol.36, p.1059-1086.

Kieso, Donald E., Jerry J. Weygandt, dan Terry D. Warfield. 2011. "Intermediate Accounting, Volume2”. Edisi IFRS. New Jersey: Joh Wiley \& Sons, Inc.

Knauer, Thorsten dan Arnt Wohrmann. 2010. Paper Presented at International Accounting and Auditing Conference "Market Reaction to Goodwill Impairments". University of Muenster. 
Lapointe, Pascale et. al. 2009. The International Journal of Accounting "Value Relevance and Timeliness of Transitional Goodwill- Impairment Losses: Evidence from Canada". No. 23.

Lapointe, Pascale. 2006. Causes and Consequences of Transitional Goodwill Impairment Losses. Social Science Research Network.

Lemans, Jamilla. 2010. "Goodwill Impairment as a Tool for Earning Management”. Master Thesis, Erasmus University.

Pajunen, Kati dan Jani Saastamoinen . 2011. Working Paper “Auditor's Perception of Goodwill Write-Offs under IFRS". University of Eastern Finland.

Pajunen, Kati dan Jani Saastamoinen. 2012. Working Paper “Goodwill Impairment Losses as a Managerial Losses". University of Eastern Finland

Radebaugh, Lee H., Sidney J. Grey dan Ervin L. Black. 2006. "International Accounting and Multinational Enterprises". Edisi 6. United States of America: John Wiley \& Sons, Inc.

Ramanna Karthik dan Ross L. Watts. 2011. Working Paper "Evidence on Use of Unverifiable Estimates in Required Goodwill Impairment". Harvard Business School.

Schroeder, Richard G., Myrtle W.Clark, dan Jack M. Cathey. 2011. "Financial Accounting Theory and Analysis: Text and Cases". New Jersey: John Wiley \& Sons Inc.

Schultze, Wolfgang. 2005. Schmalenbach Business Review "The Information Content of Goodwill - Impairments under FAS 142: Implications for External Analysis and Internal Control”. Vol. 57 July 2005 pp. 276 297.

Scott, William R. 2003. "Financial Accounting Theory". Edisi 3. Canada: Pearson.

Van De Poel, et.al. 2008. Paper Presented at Doctoral Colloquium and Conference of the European Accounting Association "Implementation of IFRS within Europe: The Case of Goodwill". Rotterdam.

Van Hulzen, Paul, et. al. 2011. International Journal of Economic Sciences and Applied Research "Amortization Versus Impairment of Goodwill and Accounting Quality". 4 (3): 93-118.

Wooten, Thomas C. 2003. The CPA Journal "Research About Audit Quality".

Zadeh, Amir Amel, et. al. 2013. Working Paper "Has Accounting Secured More Valuable Goodwill Disclosures". University of Cambridge and Judge Business School. 